Fifth International Conference on Sustainable Construction Materials and

Technologies. http://www.claisse.info/Proceedings.htm

\title{
FEASIBILITY OF CROSS-LAMINATED SECONDARY TIMBER
}

\author{
Colin M. Rose ${ }^{1}$, and Julia A. Stegemann ${ }^{2}$ \\ ${ }^{1}$ Department of Civil, Environmental \& Geomatic Engineering, Centre for Urban \\ Sustainability and Resilience, University College London, Gower Street, London \\ WC1E 6BT, UK; colin.rose.13@ucl.ac.uk \\ ${ }^{2}$ Department of Civil, Environmental \& Geomatic Engineering, Centre for Resource \\ Efficiency \& the Environment, University College London, Gower Street, London \\ WC1E 6BT, UK; j.stegemann@ucl.ac.uk
}

\begin{abstract}
The construction industry creates significant volumes of waste timber, much of which has residual quality and value that dissipates in conventional waste management. This research explored the novel concept of reusing secondary timber as feedstock for 'cross-laminated secondary timber' (CLST) through a review of the literature. If CLST can replace conventional cross-laminated timber (CLT), structural steel and reinforced concrete in some applications, this constitutes upcycling to displace materials with greater environmental impacts. The paper introduces the rationale for such an intervention and assesses its feasibility. It concludes with open research questions to advance the concept towards commercial application.
\end{abstract}

Keywords: Cross-laminated secondary timber, waste management

\section{INTRODUCTION}

The timber in existing building stocks represents a significant stockpile, with estimates in the range of 2.4-4.0 tonnes per capita (Höglmeier et al. 2013; Kleemann et al. 2017); in some countries, it is a greater quantity than the stock in forests managed for harvesting (Müller 2006). Upon building demolition, the cascading principles that contribute to a circular economy (Stahel 1982; Ellen MacArthur Foundation 2013) dictate that the resulting timber arisings should be reused (BioRegional 2006; Bergman et al. 2013; Bergman et al. 2010), with minimised processing and loss of performance, to maximise their useful lifespan (Sirkin \& ten Houten 1994; Fraanje 1997) and maintain storage of sequestered carbon (Husgafvel et al. 2017). The greatest opportunities for long-term use in the built environment lie 
in structural applications, as structural components have the longest lifespan (Brand 1994).

Direct reuse of timber is often impractical, for reasons including the fact that buildings are rarely designed with deconstruction and reclamation in mind (Durmišević 2015; Sassi 2004). Conventional recycling therefore involves chipping timber and downcycling it into products such as particleboard and animal bedding, which achieves reliable supply and fitness for purpose, but with a considerable loss of performance and value; the recycled products are relatively short-lived and represent the final material use before incineration or disposal. Any reclaimed whole members that reach salvage yards tend towards shorter usable lengths and smaller effective sections. They may retain their mechanical characteristics (Falk et al. 2008), but are typically sold 'as seen' and without warranties, failing to provide certainty over supply and fitness for purpose, which restricts demand from mainstream construction (Rose \& Stegemann 2018b).

Improving the supply of secondary structural timber to the construction industry could mitigate future supply risks, including increased competition for the use of land (Allwood et al. 2011), price rises if timber supply is curtailed while demand rises (Defra 2010), and future planning requirements, contractual obligations and regulation of whole-life greenhouse gas (GHG) emissions (BIS 2010; Giesekam et al. 2014; Steele et al. 2015; Giesekam et al. 2015; Papakosta \& Sturgis 2017). However, to capitalise on residual timber properties, there is a need for new processes that upcycle secondary timber, and recertify the resulting products to meet mainstream construction industry requirements (Rose \& Stegemann 2018b; Rose \& Stegemann 2018a). This research proposes to exploit secondary timber as a feedstock for cross-laminated secondary timber (CLST).

\section{REVIEW}

The use of CLT has grown considerably in recent years; its advantages are well understood in academia, and it is gaining acceptance across industry (Jones et al. 2016). Production capacity is rising, with Austria and Germany reporting 20\% year on year increases (Hairstans 2016) and double-digit annual growth rates expected over the next decade (Brandner et al. 2016). Replacement of primary feedstock for CLT with secondary timber holds promise: crosswise lamination of multiple lamellae minimises the detrimental influence of natural defects in individual boards of primary timber (Concu et al. 2017; Taylor 2013), and the detrimental influence of manmade defects arising from the previous use of secondary timber would similarly be minimised. Laminated timber products also provide an opportunity to control the location of higher grade timber in the engineered section to maximise structural benefit. Glulam standard BS EN 14080:2013 (BSI 2014a) already endorses production of structurally efficient sections from variable quality wood, with stiffer and stronger timber at the extremities of the section, and weaker timber at the neutral axis, the function of the latter being primarily to increase the second moment of inertia by separating the outer lamellae. Similarly, in typical current European practice based on Mechanically Jointed Beams Theory (MJBT, also known as the Gamma Method; Eurocode 5 (BSI 2014b, Christovasilis et al. 2016)), strength and 
stiffness calculations for CLT products largely disregard the contributions of the lamellae crosswise to the load application, e.g., horizontally-oriented lamellae in a vertical compression element (wall), or lamellae oriented orthogonally to the span in a bending element (floor) (Milner 2017).

Mining the existing timber stocks in cities could enable their greater self-sufficiency in managing their construction and demolition waste (e.g., GLA 2017) and help to localise CLT supply chains (Brunner 2011). For example, in the UK, which has little forest cover (12\% of total land area, compared to 47\% in Austria; FAO 2011), CLT is imported from Austria and other parts of Europe. On the other hand, the timber fraction of UK construction and demolition waste is estimated at 0.9-5.0 Mtpa, of which something in the region of 55-75\% is solid wood, and a growing proportion of this waste is exported for energy generation in Europe (Pöyry 2009; Tolvik 2011; WRAP 2011; Defra 2012; Defra 2016). Using secondary timber stocks would contribute to policy goals: fostering a more circular economy with new employment in manufacturing (Gavron et al. 2017) and reindustrialisation of the European (and British) economy (European Commission 2012; European Commission 2014; European Commission 2015), and production of net negative- or low-carbon building components. The lifespan at high value of timber in a circular economy could be further extended by designing the CLST panels for deconstruction and reuse (Campbell 2018). If CLST can replace conventional CLT, structural steel and reinforced concrete in some applications, this is enhancement of the performance of waste: upcycling into a new closed loop.

Timber for different structural uses is graded based on its tree species, origin, strength reducing characteristics and geometrical characteristics (BSI 2016a; BSI 2016b; BSI 2017; BSI 2013). CLT is typically made from Norway spruce and common strength classes are C24, C18 and C16 (Brandner 2013). There is growing interest in use of locally abundant, under-utilised timber resources for which there are no established structural properties as CLT feedstock (Espinoza \& Buehlmann 2018). Examples include the use of Sitka spruce (Crawford et al. 2014; Crawford et al. 2015; Sikora et al. 2016), Italian marine pine (Fragiacomo et al. 2015; Concu et al. 2017), European beech (Franke 2016; Aicher, Christian, et al. 2016; Aicher, Hirsch, et al. 2016), large-leaf beech (Essoua Essoua \& Blanchet 2017), Southern pine (Hindman \& Bouldin 2015; Sharifnia \& Hindman 2017), hybrid poplar (Kramer et al. 2014), tulipwood (Mohamadzadeh \& Hindman 2015; Thomas \& Buehlmann 2017), poplar (Wang et al. 2014), eucalyptus (Liao et al. 2017) and Japanese cedar (Okabe et al. 2014). Investment in a new CLT and glulam plant in Alabama that exploits local Southern pine (Vloysky 2017) suggests that alternative feedstocks to those used in typical European CLT production can become economically viable if abundant local materials are used.

Although European Standard BS EN 16351:2015 (BSI 2015) does not allow used wood in CLT as a precaution, it has previously been suggested that secondary timber could be used to produce engineered wood products (Geldermans 2009; Sakaguchi 2014; Bergsagel 2016; Kremer \& Symmons 2015). Researchers at the University of Utah with industry partners investigated the manufacture of interlocking 'ICLT' without adhesives or fasteners (Smith 2011). Their work considered sourcing the 
timber from existing buildings, but they chose instead to explore pilot manufacture and mechanical testing of ICLT using standing trees that have been affected by pine bark beetle (Wilson 2012). The present authors conducted preliminary research to explore the technical feasibility of using secondary timber to produce CLST (Rose et al. 2018).

For certifiable mass production of CLT, consistency of supply of raw materials and raw material quality is crucial. However, as a natural material, the properties of primary timber are variable: the extent of variability can be greater between two members sawn from the same tree than from two different species (Ridley-Ellis et al. 2016). Strength classes are based on characteristic properties and individual members may well fall short of the characteristic values; BS EN 16351:2015 (BSI 2015) makes allowance for this by permitting deviation of up to $35 \%$ from the declared strength parallel to the grain in $10 \%$ of boards in any given lamella. Despite this acceptance of uncertainty, achieving equivalent levels of confidence in secondary timber requires an understanding of how ageing and use affect both its characteristics and the variability of these characteristics.

Natural ageing results from biological, chemical, mechanical, thermal, water and other weathering effects (Nilsson \& Rowell 2012). When 'stored' in use in a building's structure, timber is typically protected from weathering, and moisture content should be below $20 \%$, such that it is largely protected from biological degradation. Softwoods, which make up the majority of secondary timber, may benefit from increasing cellulose crystallisation for the first few hundred years of life (Kohara \& Okamoto 1955; Nakao et al. 1989), leading to increases in density, hardness, dimensional stability, tensile strength, and Young's modulus (the ratio of elastic stress and corresponding strain, also known as the Modulus of Elasticity, MOE) (Lionetto et al. 2012). However, two recent review papers (Cavalli et al. 2016; Kránitz et al. 2016) found that there has been no overall consensus on the effect of natural ageing on strength, stiffness and other physical properties of various species of timber. Ageing during use inside a building, e.g., through fluctuations in temperature, humidity or the effects of ultraviolet radiation, may affect timber's mechanical properties, but findings are often ambiguous, and could result from other factors (Froidevaux \& Navi 2013; Sonderegger et al. 2015; Kránitz et al. 2016; Holzer et al. 1989; Attar-Hassan 1976). Surface characteristics of timber change with time (Kránitz et al. 2016) and, for use in CLST, the faces of secondary boards would need to be planed to provide good surfaces for durable bonding, as well as to produce consistent board thicknesses.

It is well established that timber can carry substantially greater loads over a short period of time than for long durations of loading; Fridley et al. (1995) present a history of research investigating this 'duration of load' (DOL) effect going back to the eighteenth century. Much of the research into creep-rupture, the failure mode attributed to the DOL effect, uses results of impact testing and short- and long-term loading to estimate expected times until failure for loading at a given stress ratio (i.e., a proportion of assumed short-term strength; Hoffmeyer 2003). Higher moisture content is known to produce a shorter time to failure, while cyclical changes in moisture content further accelerate creep and reduce time to creep-failure 
(Hoffmeyer \& Sørensen 2007). Since at least the nineteenth century, it has been understood that timber structures intended for long life should be designed with a safety factor such that only one-half to two-thirds of the material's short-term strength is relied upon (Fridley et al. 1995). The effects of DOL and moisture content have long been incorporated into design standards for timber building structures; e.g., Eurocode 5 (BSI 2014b) sets out strength modification factors ranging from 0.50 for 'permanent' loading ( $>10$ years) in climatic conditions that may lead to moisture content $>20 \%$; 0.60 for permanent loading where moisture content is $<20 \%$; to 1.10 for instantaneous loading for moisture content $<20 \%$.

It is important to note that DOL effects are particularly significant in the short- and medium-terms. In the long-term, a difference of double or triple the anticipated load duration affects the load capacity by only a few percentage points (Hoffmeyer 2003). The major reduction in load capacity predicted by DOL modelling occurs over the first few years - and certainly within a period of time in the order of a normal building lifespan of, say, 50 years - with further degradation beyond that time found to be minimal in most DOL research (Wood 1960; Dinwoodie 1975; Hoffmeyer 2003). This seems to bear out the observation that many very old timber structures remain standing. Arguably, therefore, secondary use of timber simply extends its anticipated load duration and could be expected to produce only minor reduction in load capacity, compared to the strength modification factors taken into account in its first use.

Nevertheless, uncertainties remain. Timber that has been exposed to high and especially to fluctuating moisture content, for instance through external use, is likely to have experienced significant strength loss and is unlikely to be suitable for reuse in a structural application. Evidence suggests that large solid timber members used internally do not undergo large moisture fluctuations (Holzer et al. 1989), but this may not always hold true. Repeated loading may have caused fatigue damage to have accumulated in secondary timber that cannot be perceived (Hoffmeyer 2003). The stress ratio at which loss of strength becomes permanent appears to vary widely depending on timber species and testing conditions, with an average perhaps in the region of 0.40 (Dinwoodie 1975). On the other hand, different conclusions arise from the extensive work by the USDA Forest Products Laboratory on the structural properties and grading of North American secondary timber (Falk et al. 2008; Falk et al. 1990; Falk et al. 2012; Falk et al. 2000; Falk 2002; Falk, Green, et al. 1999; Falk et al. 2003; Falk \& Green 1999; Janowiak et al. 2014; Falk, DeVisser, et al. 1999; Falk 1999; Williams et al. 2000; Fridley et al. 1996). They acknowledge that 'overloading' can degrade timber, but their testing indicates that MOE and bending strength appear to be unaffected by ageing and previous load history (Falk et al. 2008), and that reductions in strength arise from observable macro-level defects, such as nail holes, rather than from the molecular structure of aged timber. They therefore recommend regrading before reuse but conclude that wholesale visual downgrading is currently too conservative. The group consider some reuse options for different species of reclaimed timber (Janowiak et al. 2007; Janowiak et al. 2005), including nail-laminated posts (Janowiak et al. 2014). They were able to conclude that the tested material has potential for reuse in this structural application, but have not extended their investigation into CLT. 
The fabrication process and mechanical properties of CLST were tested by the present authors (Rose et al. 2018) in small-scale laboratory experiments. These showed no significant difference between the compression stiffness and strength of CLST and a control. Finite element modelling suggested that typical minor defects in secondary timber have only a small effect on CLST panel stiffness in compression and bending. Mechanically Jointed Beams Theory calculations to examine the potential impacts of secondary timber ageing on CLST panels found that this has little effect on compression stiffness if only the crosswise lamellae are replaced.

\section{FURTHER RESEARCH}

As a pilot research project, the findings from Rose et al. (2018) stimulate further research questions to advance the concept of CLST towards commercial application through additional laboratory- and pilot-scale experiments and modelling:

- What are the properties and variability of secondary timber feedstock? How can these best be characterised for commercial-scale quality control?

- How does variability in the properties of secondary timber affect the variability of CLST stiffness and strength properties?

- Does physical testing bear out modelled findings on the effectiveness of various CLST formats?

- Is there any difference in the bond strength, dimensional stability, rolling shear behaviour and fire behaviour of CLST and conventional CLT?

- What quantities of secondary timber are available and useable in CLST, and at what cost relative to conventional CLT?

- What scale of operation is needed to be commercially viable?

- Can conventional PUR and melamine-urea-formaldehyde adhesives be replaced with a non-toxic biodegradable alternative, or other joining technique (e.g., Brettstapel, friction-welding of wood: Stamm et al. 2005; Hahn et al. 2014; Buck et al. 2015; Wójcik \& Strumiłło 2014; Ramage et al. 2017), for a product that is consistent with biological metabolism in a circular economy (Campbell 2018; McDonough \& Braungart 2002)?

\section{REFERENCES}

Aicher, S., Christian, Z. \& Hirsch, M., 2016. Rolling shear modulus and strength of beech wood laminations. Holzforschung, 70(8), pp.773-781.

Aicher, S., Hirsch, M. \& Christian, Z., 2016. Hybrid cross-laminated timber plates with beech wood cross-layers. Construction and Building Materials, 124, pp.1007-1018. doi: 10.1016/j.conbuildmat.2016.08.051.

Allwood, J.M. et al., 2011. Material efficiency: A white paper. Resources, Conservation and Recycling, 55(3), pp.362-381. doi: 10.1016/j.resconrec.2010.11.002.

Attar-Hassan, G., 1976. The Effect of Ageing on the Mechanical Properties of Eastern White Pine. Bulletin of the Association for Preservation Technology, 8(3), pp.64-73. Available at: http://www.jstor.org/stable/1493572. 
Bergman, R.D. et al., 2013. Life-Cycle Energy and GHG Emissions for New and Recovered Softwood Framing Lumber and Hardwood Flooring Considering End-of-Life Scenarios, Madison, WI, USA.

Bergman, R.D. et al., 2010. Using Reclaimed Lumber and Wood Flooring in Construction: Measuring Environmental Impact Using Life- Cycle Inventory Analysis. In Proceedings of the International Convention of Society of Wood Science and Technology and United Nations Economic Commission for Europe - Timber Committee. Geneva, Switzerland, pp. 1-11. Available at: http://128.104.77.228/documnts/pdf2010/fpl_2010_bergman002.pdf.

Bergsagel, D., 2016. Disassembling Detroit: how deconstructing the post- industrial Rust Belt could give structural timber another life. Structural Engineer, (November), pp.12-19.

BioRegional, 2006. Reclaimed Building Materials in the Development of the Thames Gateway, Wallington, UK.

BIS, 2010. Low Carbon Construction: Innovation \& Growth Team Final Report, London, UK. Available at: https://www.gov.uk/government/uploads/system/uploads/attachment_data/file/ 31773/10-1266-low-carbon-construction-IGT-final-report.pdf.

Brand, S., 1994. How buildings learn: What happens after they're built, New York: Viking.

Brandner, R. et al., 2016. Cross laminated timber (CLT): overview and development. European Journal of Wood and Wood Products, 74(3), pp.331351.

Brandner, R., 2013. Production and Technology of Cross Laminated Timber (CLT): A state-of-the-art Report,

Brunner, P.H., 2011. Urban mining a contribution to reindustrializing the city. Journal of Industrial Ecology, 15(3), pp.339-341.

BSI, 2017. BS 4978:2007+A2:2017: Visual strength grading of softwood Specification, UK: BSI Standards Publication.

BSI, 2014a. BS EN 14080:2013: Timber structures - Glued laminated timber and glued solid timber - Requirements, UK: BSI Standards Publication.

BSI, 2016a. BS EN 14081-1:2016: Timber structures - Strength graded structural timber with rectangular cross section, Part 1: General requirements, UK: BSI Standards Publication.

BSI, 2015. BS EN 16351:2015: Timber structures - Cross laminated timber Requirements, UK: BSI Standards Publication.

BSI, 2013. BS EN 1912:2012: Structural Timber - Strength classes - Assignment of visual grades and species, UK: BSI Standards Publication.

BSI, 2014b. BS EN 1995-1-1:2004+A2:2014: Eurocode 5: Design of timber structures - Part 1-1: General - Common rules and rules for buildings, UK: BSI Standards Publication.

BSI, 2016b. BS EN 338:2016: Structural timber - Strength classes, UK: BSI Standards Publication.

Buck, D. et al., 2015. Comparison of different assembling techniques regarding cost, durability, and ecology - a survey of multi-layer wooden panel assembly load-bearing construction elements. BioResources, 10(4), pp.8378-8396.

Campbell, A., 2018. Mass Timber in the Circular Economy: Paradigm in Practice? 
Proceedings of Institution of Civil Engineers: Engineering Sustainability, pp.1-12.

Cavalli, A. et al., 2016. A review on the mechanical properties of aged wood and salvaged timber. Construction and Building Materials, 114, pp.681-687. doi: 10.1016/j.conbuildmat.2016.04.001.

Christovasilis, I.P. et al., 2016. Evaluation of the mechanical properties of cross laminated timber with elementary beam theories. Construction and Building Materials, 122, pp.202-213. doi: 10.1016/j.conbuildmat.2016.06.082.

Concu, G. et al., 2017. Grading of maritime pine from Sardinia (Italy) for use in cross-laminated timber. Proceedings of the Institution of Civil Engineers Construction Materials, pp.1-11. Available at: http://www.icevirtuallibrary.com/doi/10.1680/jcoma.16.00043.

Crawford, D. et al., 2015. Viability of cross-laminated timber from UK resources. Proceedings of the ICE - Construction Materials, 168, pp.110-120.

Crawford, D., Hairstans, R. \& Smith, R.E., 2014. Feasibility of Cross-Laminated Timber Production from UK Sitka spruce. In R. Harris, A. Ringhofer, \& G. Schickhofer, eds. Focus Solid Timber Solutions - European Conference on Cross Laminated Timber (CLT). Graz, Austria: The University of Bath, pp. 37-52.

Defra, 2010. Review of the Future Resource Risks Faced by UK Business and an Assessment of Future Viability, London, UK.

Defra, 2016. UK Statistics on Waste, York, UK. Available at: https://www.gov.uk/government/statistics/uk-waste-data.

Defra, 2012. Wood waste: A short review of recent research, London, UK.

Dinwoodie, J.M., 1975. Timber-a review of the structure-mechanical property relationship. Journal of Microscopy, 104(1), pp.3-32.

Durmišević, E., 2015. Buildings as Material Banks. In M. R. Popovac et al., eds. The 3rd International Conference "The Importance of Place." Sarajevo: CICOPBH, pp. 139-152.

Ellen MacArthur Foundation, 2013. Towards the Circular Economy, vol. 1, Espinoza, O. \& Buehlmann, U., 2018. Cross-Laminated Timber in the USA: Opportunity for Hardwoods? Current Forestry Reports, 4(1), pp.1-12. Available at: http://link.springer.com/10.1007/s40725-018-0071-x.

Essoua Essoua, G.G. \& Blanchet, P., 2017. Cross laminated timber made from large-leaf beech: Production, characterization and testing. In V. Möttönen \& E. Heinonen, eds. 6th International Scientific Conference on Hardwood Processing (ISCHP2017). Lahti, Finland: Natural Resources Institute Finland, pp. 208-212. Available at: http://jukuri.luke.fi/handle/10024/541001.

European Commission, 2015. Closing the loop - An EU action plan for the circular economy, Brussels, Belgium: European Commission. Available at: http://eurlex.europa.eu/legal-content/EN/TXT/?uri=CELEX:52015DC0614.

European Commission, 2012. European Resource Efficiency Platform (EREP): Manifesto \& Policy Recommendations, Brussels, Belgium: European Commission. Available at: http://ec.europa.eu/environment/resource_efficiency/documents/erep_manifest o_and_policy_recommendations_31-03-2014.pdf.

European Commission, 2014. Towards a circular economy: A zero waste 
programme for Europe, Brussels, Belgium: European Commission.

Falk, R.H., DeVisser, D., et al., 1999. Effect of damage on the grade yield of recycled lumber. Forest Products Journal, 49(7/8), pp.71-79. Available at: http://web.b.ebscohost.com/ehost/pdfviewer/pdfviewer?vid=1\&sid=8d6da7959465-4a7e-b88c-3d2719062f49\%40sessionmgr103.

Falk, R.H. et al., 2003. Effect of drilled holes on the bending strength of large dimension Douglas-fir lumber. Forest Products Journal, 53(5), pp.55-60.

Falk, R.H. et al., 2000. Engineering Evaluation of 55-Year-Old Timber from an Industrial Military Building. Forest Products Journal, 50(8939), pp.71-76.

Falk, R.H. et al., 2008. Engineering Properties of Douglas-fir Lumber Reclaimed from Deconstructed Buildings - Research Paper FPL-RP-650, Madison, WI, USA.

Falk, R.H., 1999. The properties of lumber and timber recycled from deconstructed buildings. In G. B. Walford \& D. J. Gaunt, eds. Ptec 99 - Pacific Timber Engineering Conference. Rotorua, New Zealand: Forest Research Bulletin, pp. 255-257. Available at: https://www.fpl.fs.fed.us/documnts/pdf1999/falk99b.pdf.

Falk, R.H., 2002. Wood-Framed Building Deconstruction: A Source of Lumber for Construction? Forest Products Journal, 52(3), pp.8-15. Available at: https://www.fpl.fs.fed.us/documnts/pdf2002/falk02a.pdf.

Falk, R.H., Cramer, S. \& Evans, J., 2012. Framing lumber from building removal: How do we best utilize this untapped structural resource? Forest Products Journal, 62(7-8), pp.492-499. Available at: http://www.scopus.com/inward/record.url?eid=2-s2.084883138042\&partnerID=tZOtx3y1.

Falk, R.H., Green, D. \& Lantz, S.C., 1999. Evaluation of lumber recycled from an industrial military building. Forest Products Journal, 49(5), pp.49-55.

Falk, R.H. \& Green, D.W., 1999. Stress Grading of Recycled Lumber and Timber. In Structures Congress: Structural Engineering in the 21st Century. American Society of Civil Engineers, pp. 650-653.

Falk, R.H., Patton-Mallory, M. \& McDonald, K.A., 1990. Nondestructive testing of wood products and structures: state-of-the-art and research needs. In H. L. M. doe Reis, ed. Nondestructive testing and evaluation for manufacturing and construction. Champaign, IL: Hemisphere Publishing Corp., pp. 137-147. Available at: http://linkinghub.elsevier.com/retrieve/pii/096386959190857Y.

FAO, 2011. State of the World's Forests 2011, Rome. Available at: http://www.fao.org/docrep/013/i2000e/i2000e.pdf.

Fraanje, P.J., 1997. Cascading of pine wood. Resources, Conservation and Recycling, 19(1), pp.21-28.

Fragiacomo, M., Riu, R. \& Scotti, R., 2015. Can Structural Timber Foster Short Procurement Chains within Mediterranean Forest? A Research Case in Sardinia. , 6(1), pp.107-117.

Franke, S., 2016. Mechanical Properties of Beech CLT. In J. Eberhardsteiner et al., eds. Proceedings of the WCTE 2016 World Conference on Timber Engineering. Vienna, Austria: Vienna University of Technology, Austria, pp. 22-25.

Fridley, K.J. et al., 1996. Effect of 85 years of service on mechanical properties of 
timber roof members. Part 1. Experimental observations. Forest products journal, 46(5), pp.72-78.

Fridley, K.J., Hunt, M.O. \& Senft, J.F., 1995. Historical perspective of duration-ofload concepts. Forest Products Journal, 45(Apr), pp.1-6.

Froidevaux, J. \& Navi, P., 2013. Aging law of spruce wood. Wood Material Science and Engineering, 8(1), pp.46-52.

Gavron, N. et al., 2017. Designed, sealed, delivered: The contribution of offsite manufactured homes to solving London's housing crisis, London.

Geldermans, R.J., 2009. Cradle-to-Cradibility: Two Material Cycles and the Challenges of Closed Loops in Construction. TU Delft / Leiden University, the Netherlands.

Giesekam, J. et al., 2014. The greenhouse gas emissions and mitigation options for materials used in UK construction. Energy and Buildings, 78, pp.202-214. doi: 10.1016/j.enbuild.2014.04.035.

Giesekam, J., Barrett, J.R. \& Taylor, P., 2015. Construction sector views on low carbon building materials. Building Research \& Information, 3218(October 2015), pp.1-23. Available at: http://www.tandfonline.com/doi/full/10.1080/09613218.2016.1086872.

GLA, 2017. The London Plan: Draft for public consultation, London. Available at: https://www.london.gov.uk/what-we-do/planning/london-plan/new- londonplan.

Hahn, B. et al., 2014. Moment resisting connections composed of friction-welded spruce boards: Experimental investigations and numerical strength prediction. European Journal of Wood and Wood Products, 72(2), pp.229-241.

Hairstans, R., 2016. Taking timber beyond traditional boundaries. Timber 2016 Industry Yearbook, pp.38-43. Available at: https://software.trada.co.uk/publications/download/?id=1C5FCE68-901742E4-94C7-87D4EF5BECC5.

Hindman, D.P. \& Bouldin, J.C., 2015. Mechanical Properties of Southern Pine Cross-Laminated Timber. Journal of Materials in Civil Engineering, 27(9), pp.1-7.

Hoffmeyer, P., 2003. Strength under long-term loading. In S. Thelandersson \& H. J. Larsen, eds. Timber Engineering. Chichester, UK: John Wiley \& Sons, pp. 131-152. Available at: https://books.google.co.uk/books?id=sssVW7-YynwC.

Hoffmeyer, P. \& Sørensen, J.D., 2007. Duration of load revisited. Wood Science and Technology, 41(8), pp.687-711.

Höglmeier, K., Weber-Blaschke, G. \& Richter, K., 2013. Potentials for cascading of recovered wood from building deconstruction - A case study for south-east Germany. Resources, Conservation and Recycling, 78, pp.81-91. doi: 10.1016/j.resconrec.2013.07.004.

Holzer, S.M., Loferski, J.R. \& Dillard, D.A., 1989. A review of creep in wood: concepts relevant to develop long-term behavior predictions for wood structures. Wood and Fiber Science, 21(4), pp.376-392. Available at: papers3://publication/uuid/84579A14-FFFB-4B43-A02D-4E5E3BF5197A.

Husgafvel, R. et al., 2017. Forest sector circular economy development in Finland: A regional study on sustainability driven competitive advantage and an assessment of the potential for cascading recovered solid wood. Journal of 
Cleaner Production, 181, pp.483-497. Available at:

http://linkinghub.elsevier.com/retrieve/pii/S0959652617331475.

Janowiak, J.J. et al., 2014. Mechanical performance of nail-laminated posts manufactured from reclaimed chromated copper arsenate-treated decking lumber. Forest Products Journal, 64(1/2), pp.55-63.

Janowiak, J.J. et al., 2005. Remilling of salvaged wood siding coated with leadbased paint. Part I. Lead exposure. Forest Products Journal, 55(7-8), pp.7680 .

Janowiak, J.J., Falk, R.H. \& Kimmel, J., 2007. Feasibility of producing valueadded wood products from reclaimed hemlock lumber, Available at: http://www.fpl.fs.fed.us/documnts/fplrp/fpl_rp645.pdf.

Jones, K. et al., 2016. Adoption of unconventional approaches in construction: The case of cross-laminated timber. Construction and Building Materials, 125, pp.690-702. doi: 10.1016/j.conbuildmat.2016.08.088.

Kleemann, F. et al., 2017. GIS-based Analysis of Vienna's Material Stock in Buildings. Journal of Industrial Ecology, 21(2), pp.368-380.

Kohara, J. \& Okamoto, H., 1955. Studies of Japanese old timbers. Sci Rep Saikyo Univ, 7((1a)), pp.9-20. doi: 10.2472/jsms1952.10.894.

Kramer, A., Barbosa, A.R. \& Sinha, A., 2014. Viability of Hybrid Poplar in ANSI Approved Cross-Laminated Timber Applications. Journal of Materials in Civil Engineering, 26(7), p.06014009. Available at: http://ascelibrary.org/doi/10.1061/\%28ASCE\%29MT.1943-5533.0000936.

Kránitz, K. et al., 2016. Effects of aging on wood: a literature review. Wood Science and Technology, 50(1), pp.7-22.

Kremer, P.D. \& Symmons, M.A., 2015. Mass timber construction as an alternative to concrete and steel in the Australia building industry: a PESTEL evaluation of the potential. International Wood Products Journal, 6(3), pp.138-147. doi: 10.1179/2042645315Y.0000000010.

Liao, Y. et al., 2017. Feasibility of manufacturing cross-laminated timber using fast-grown small diameter eucalyptus lumbers. Construction and Building Materials, 132, pp.508-515. doi: 10.1016/j.conbuildmat.2016.12.027.

Lionetto, F. et al., 2012. Monitoring wood degradation during weathering by cellulose crystallinity. Materials, 5(10), pp.1910-1922.

McDonough, W. \& Braungart, M., 2002. Cradle to Cradle: Remaking the Way We Make Things 1st ed., North Point Press. Available at: http://www.amazon.com/exec/obidos/redirect?tag=citeulike0720\&path=ASIN/0865475873.

Milner, M., 2017. The durability and structural design of cross-laminated timber (CLT) structures. Timber 2017 Industry Yearbook, pp.90-97.

Mohamadzadeh, M. \& Hindman, D., 2015. Mechanical Performance of YellowPoplar Cross Laminated Timber, Blacksburg, VA, USA. Available at: https://vtechworks.lib.vt.edu/bitstream/handle/10919/64863/Mohamadzadeh_ Hindman_2015.pdf? sequence $=1$ \&isAllowed $=\mathrm{y}$.

Müller, D.B., 2006. Stock dynamics for forecasting material flows - Case study for housing in The Netherlands. Ecological Economics, 59(1), pp.142-156.

Nakao, T. et al., 1989. Short Note Long-Term Changes in Degree of Crystallinity of Wood Cellulose. Holzforschung, 43(6), pp.419-420. 
Nilsson, T. \& Rowell, R., 2012. Historical wood - structure and properties. Journal of Cultural Heritage, 13(3 SUPPL.), pp.S5-S9. Available at: http://dx.doi.org/10.1016/j.culher.2012.03.016.

Okabe, M. et al., 2014. Prediction of bending stiffness and moment carrying capacity of sugi cross-laminated timber. Journal of Wood Science, 60(1), pp.49-58.

Papakosta, A. \& Sturgis, S., 2017. RICS professional statement: Whole life carbon assessment for the built environment, 1st edition, London. Available at: http://www.rics.org/Global/Whole_life_carbon_assessment_for_the_BE_PGg uidance_2017.pdf.

Pöyry, 2009. Wood Waste Market in the UK, Banbury, UK. Available at: http://www.wrap.org.uk/sites/files/wrap/Wood waste market in the UK.pdf.

Ramage, M.H. et al., 2017. The wood from the trees: The use of timber in construction. Renewable and Sustainable Energy Reviews, 68(October 2016), pp.333-359.

Ridley-Ellis, D., Stapel, P. \& Bano, V., 2016. Strength grading of sawn timber in Europe: an explanation for engineers and researchers. European Journal of Wood and Wood Products, 74(3), pp.291-306.

Rose, C. et al., 2018. Cross-Laminated Secondary Timber: Experimental Testing and Modelling the Effect of Defects and Reduced Feedstock Properties. Sustainability, 10(11), p.4118. Available at: http://www.mdpi.com/20711050/10/11/4118.

Rose, C.M. \& Stegemann, J.A., 2018a. Characterising Existing Buildings as Material Banks (E-BAMB) to Enable Component Reuse. Proceedings of the Institution of Civil Engineers - Engineering Sustainability, 00074, pp.1-42. doi: $10.1680 /$ jensu.17.00074.

Rose, C.M. \& Stegemann, J.A., 2018b. From Waste Management to Component Management in the Construction Industry. Sustainability, 10(1), p.229. Available at: http://www.mdpi.com/2071-1050/10/1/229/.

Sakaguchi, D., 2014. Potential for Cascading Wood From Building. Aalto University. Available at: https://aaltodoc.aalto.fi/handle/123456789/18125.

Sassi, P., 2004. Designing buildings to close the material resource loop.

Proceedings of the ICE-Engineering Sustainability, (September), pp.163-171. Available at: http://www.icevirtuallibrary.com/content/article/10.1680/ ensu.2004.157.3.163 [Accessed February 3, 2015].

Sharifnia, H. \& Hindman, D.P., 2017. Effect of manufacturing parameters on mechanical properties of southern yellow pine cross laminated timbers. Construction and Building Materials, 156, pp.314-320. doi: 10.1016/ j.conbuildmat.2017.08.122.

Sikora, K.S., McPolin, D.O. \& Harte, A.M., 2016. Effects of the thickness of crosslaminated timber (CLT) panels made from Irish Sitka spruce on mechanical performance in bending and shear. Construction and Building Materials, 116, pp.141-150. doi:10.1016/j.conbuildmat.2016.04.145.

Sirkin, T. \& ten Houten, M., 1994. The cascade chain. A theory and tool for achieving resource sustainability with applications for product design. Resources, Conservation and Recycling, 10(3), pp.213-276.

Smith, R.E., 2011. Interlocking Cross-Laminated Timber: alternative use of waste 
wood in design and construction. In V. Hui \& T. Meyer Boake, eds. BTES

Conference 2011 - Convergence and Confluence. Toronto, Ontario, Canada:

Building Technology Educators' Society. doi:

10.1.1.475.2367\&rep=rep1\&type=pdf.

Sonderegger, W. et al., 2015. Aging effects on physical and mechanical properties of spruce, fir and oak wood. Journal of Cultural Heritage, 16(6), pp.883-889. doi: 10.1016/j.culher.2015.02.002.

Stahel, W.R., 1982. The Product-Life Factor. In S. G. Orr, ed. An Inquiry into the Nature of Sustainable Societies: The Role of the Private Sector. pp. 72-96.

Stamm, B., Natterer, J. \& Navi, P., 2005. Joining of wood layers by friction welding. Journal of Adhesion Science and Technology, 19(13-14), pp.11291139.

Steele, K., Hurst, T. \& Giesekam, J., 2015. Green Construction Board Low Carbon Routemap for the Built Environment: 2015 Routemap Progress - Technical Report, London, UK. Available at:

http://www.greenconstructionboard.org/otherdocs/2015 Built environment low carbon routemap progress report 2015-12-15.pdf.

Taylor, L., 2013. Building the future - with cross-laminated timber. In Touch with Timber, (14), pp.18-19. Available at: http://www.trada.co.uk/publications/download/?id=B4CE5663-42A2-48EFAC82-72345E9F6AB1.

Thomas, R.E. \& Buehlmann, U., 2017. Using Low-Grade Hardwoods for CLT Production: A Yield Analysis. In V. Möttönen \& E. Heinonen, eds. 6th International Scientific Conference on Hardwood Processing (ISCHP2017). Lahti, Finland: Natural Resources Institute Finland, pp. 199-206.

Tolvik, 2011. 2011 Briefing Report: The UK Waste Wood Market, Available at: http://www.tolvik.com/markets-and-data/reports/2011_UK_Waste_Wood.pdf.

Vloysky, R.P., 2017. International Beams Announces Innovative Wood Products Manufacturing Facility Construction in Dothan, Alabama, Baton Rouge, LA, USA. Available at: http://www.lfpdc.lsu.edu/publications/bits/2017/20171013International-Beams-Announces-Innovative-Wood-Products-ManufacturingFacility-Construction-in-Dothan-Alabama.pdf.

Wang, Z. et al., 2014. Feasilibity of Using Poplar As Cross Layer To Fabricate Cross-Laminated Timber. In Proceedings of the 13th World Conference on Timber Engineering. Quebec City, Canada.

Williams, J.M. et al., 2000. Failure modeling of sawn lumber with a fastener hole. Finite elements in analysis and design, 36(1), pp.83-98.

Wilson, D.E., 2012. Structural Properties of ICLT Wall Panels Composed of Beetle Killed Wood. Brigham Young University. Available at: https://scholarsarchive.byu.edu/etd/3230\%0AThis.

Wójcik, M. \& Strumiłło, J., 2014. Behaviour-based Wood Connection as a Base for New Tectonics. In pp. 170-184.

Wood, L.W., 1960. Relation of strength of wood to duration of load, Madison, Wis., USA.

WRAP, 2011. Market situation report: Realising the value of recovered wood, Banbury, UK. 